\title{
IMPACT OF A SHORT-TERM SCHOOL VEGETABLE GARDENS PROGRAM ON FOOD-RELATED BEHAVIOR OF PRESCHOOLERS AND THEIR MOTHERS. SÃO PAULO, BRAZIL
}

\section{IMPACTO DE UN PROGRAMA DE HUERTAS ESCOLARES DE CORTA DURACIÓN EN LAS CONDUCTAS RELACIONADAS CON ALIMENTOS DE PREESCOLARES Y SUS MADRES. SAO PAULO, BRASIL}

\author{
Rachel G. Miguel (1,2,3), Daniza M. Ivanovic $(1,2,4)$
}

(1) Master of Public Health Program, School of Public Health, Loma Linda University, California USA.

(2) Adventist University of Chile, Campus Las Mariposas, Chillán. Chile

(3) Universidade Adventista de São Paulo (UNASP). São Paulo. Brazil.

(4) Institute of Nutrition and Food Technology (INTA), University of Chile. Santiago, Chile.

\begin{abstract}
The aim of this study was to evaluate the impact of a short-term school vegetable gardens program (VEGAPRO) focused on preschoolers and their mothers from São Paulo, Brazil, on food-related behavior (FRB) as regards to vegetable consumption. The total population comprised 231dyads mother-preschooler randomly distributed in: control group (CG, $n=103)$, with no participation in VEGAPRO, and experimental group $(E G, n=128)$, with participation of preschooler in VEGAPRO. However, 38 and 60 dyads in the CG and EG, respectively, finished the VEGAPRO. Preschoolers enrolling in VEGAPRO increased the number of daily meals and the frequency with which they consume vegetables, as well as the number of vegetables that they consumed $(P<0.02)$. Mothers from the EG significantly increased the number of daily meals with which they consumed vegetables $(P<0.01)$. These findings underline the importance of implementing VEGAPRO at an early age to promote a healthy lifestyle. Key words: Health education, health promotion, vegetables, eating behavior, Brazil.
\end{abstract}

Este trabajo fue recibido el 8 de Junio de 2010 y aceptado para ser publicado el 18 de Mayo de 2011.

\section{INTRODUCTION}

Several studies have confirmed that a diet rich in fruits and vegetables daily reduces the incidence of obesity levels, heart disease, stroke, diabetes and cancer (1-6).

The World Health Organization (WHO) and the International Association for Cancer Research have implemented the "5-a-Day for Better Health Program" in more than 40 countries around the world (7-9). The "5-a-Day for Better Health Program" was started in 1991 in the United States to promote the consumption of 5 or more servings of fruits and vegetables every day. The National Cancer Institute and the Produce for Better Health Foundation, which represents the fruit and vegetable industry, jointly sponsor the program
(7-9).

Vegetables and fruits provide phytochemicals and antioxidants, nutrients and dietary fibre that exert protective effects against some diseases (7-9). The phytochemicals include flavonoids, quercetin and carotentoids and the antioxidants are mainly vitamins $\mathrm{C}$ and $\mathrm{E}$ or beta-carotene that counteract the damaging effects of free radicals in the organism. The most important sources of phytochemicals are vegetables such as dark leafy greens, berries, garlic, onion, carrots, beets, apples and red grapes; the darker the colour, the richer the vegetable is in antioxidants and phytochemicals (7-9).

WHO norms on diet, exercising and health focuses on the main factors contributing to the increase of chronic, non-transmissible diseases; the most frequent of 
these are obesity-related conditions such as cardiovascular diseases, type II diabetes mellitus and cancer. WHO emphasizes the need to decrease the intake of animal fats, trans fatty acids, salt, simple sugars and proposes to increase the consumption of fruits, vegetables and of physical activity (10-11).

Health promotion programs focused on children and adolescents with the aim to increase vegetable and fruit consumption and to prevent the chronic, nontransmissible diseases have been carried out in several countries in the world (12-16). To be effective, nutrition education programmes must be part of an integral national strategy aimed at reducing nutritional problems and school vegetable gardens are a tool for the motivation of the community to decrease malnutrition (15).

Few studies have been carried out in preschoolers considering the low consumption of vegetables and fruits among this age group (17). Primary care, in order to promote healthy lifestyles, should begin at an early age with the aim of improving the quality of life of children and to prevent the chronic, non-transmissible diseases that will become manifest during adult life. WHO emphasizes that schools play an important role in preventing nutritional diseases through education programs (18). The importance of vegetable gardens to improve the nutritional status of the school-age population has been well documented (19-25). As part of this program, each school should have a piece of land to grow vegetables. Even though this activity requires time and some practice, its nutritional benefits and emotional satisfaction make implementation worthwhile (19). However, research related to quantifying the impact of vegetable gardens on nutritional status or on food-related behaviour (FRB) of school-age children at an early age hasn't been carried out (21-24). Moreover, among the operational difficulties of the School-Lunch Program in Brazil the main are the low productivity of the plots and the inefficient training of the staff (25).

The results of short-term environmental interventions which used lower prices or increased availability as strategies to increase fruit and vegetable intake including school gardening programs have been especially recommended (26). Patterns of behaviour acquired in early life affect behaviour related to food consumption for the lifetime of the individual (27). Therefore, educational interventions should start at an early age. Taking these considerations into account, the aim of this study was to evaluate the impact of a short-term school vegetable garden educational program (VEGAPRO) focused on preschoolers, on FRB as regards to vegetable consumption by preschoolers and their mothers, from school area in São Paulo, Brazil. The purpose was to confirm the hypothesis that (i) preschoolers enrolling in VEGAPRO increase the number of daily meals and the frequency with which they consume vegetables, as well as the number of vegetables that they like to consume and (ii) mothers experience positive changes in their FRB under the influence of their children.

\section{METHODS \\ Study design}

This is a qualitative-quantitative and comparative study.

\section{Population}

The target population studied comprised 231 mother-preschooler dyads of both sexes belonging to four educational establishments (two public and two private) located in the Southern part of São Paulo city. Dyads were randomly distributed in two groups each belonging to different schools with absolutely no contact among them: a control group $(\mathrm{CG}, \mathrm{n}=103)$ who did not participate in VEGAPRO and the experimental group $(\mathrm{EG}, \mathrm{n}=128)$ whose preschoolers participated in VEGAPRO. Both groups were paired by type of school, sex, socio-economic status (SES) and parent's religion, since food practices may vary depending of these variables (Table 1). SES was measured using Graffar's modified method (28). Preschooler age ranged between 4 to 6 years although it was slightly but significantly higher in the EG (5.2 \pm 0.9 years), compared with the CG (4.8 \pm 0.7 ) (Student's t test $=2.230 ; \mathrm{df}=96 ; \mathrm{p}<0.0284$ ). The field study was carried out from March to October, 2000. Of the 231 dyads, 98 completed the VEGAPRO and complete data were collected $(\mathrm{CG}, \mathrm{n}=38$ and $\mathrm{EG}$, $\mathrm{n}=60$ ); despite the considerable interest on the part of the children in participating in the VEGAPRO, they depended on their parents to answer the test who sometimes did not find time to complete the forms. As a consequence, 133 dyads did not participate in the study and their characteristics such as SES, mean age of each member, preschooler sex and religion were similar to those who completed VEGAPRO. Figure 1 indicates the flow diagram of mother-preschooler dyads and participation rates during VEGAPRO through each stage of the randomized trial. Figure 2 shows preschooler from the EG working in a vegetable garden, preparing the soil, sowing seeds, irrigating, farming and harvesting the vegetables. This study was approved by the Committee on Ethics in Studies in Humans of the School of Public Health, Loma Linda University, California, USA. The subjects' consent was obtained according to the Declaration of Helsinki (The World Medical Association, 1964) (29). 


\section{Methodological design \\ Diagnostic period (Pre-test)}

The pre-test was designed to be completed in one session, in order to determine through a test, the baseline pattern of behaviour related to vegetable consumption of both preschoolers and their mothers from CG and EG (table 2). This instrument had already been validated in studies carried out at the Institute of Nutrition and Food Technology (INTA) and considers the assessment of the food habits defined as the frequency of consumption of vegetables expressed as days per week, the number of daily meals in which preschoolers and their mothers consumed vegetables and the number of vegetables that preschooler like to consume.

\section{Vegetable gardens education program (VEGAPRO)}

VEGAPRO was developed for the preschoolers of the EG and consisted of 26 educational sessions of approximately 60 minutes each, during school hours, not counting the time that the preschoolers' teachers used to reinforce the program in the classroom. The content of each session is described in table 2. During these educational sessions, preschoolers used simple resources and tools, dependent on their chronological and psychological age, as they prepared de soil, sowed seeds, irrigated and cared for the farming growing plants, eliminating weeds, harvested the vegetables and consumed them at school and at home. At the same time, informal

\section{TABLE 1}

\section{Description of the variables considered for pairing the study groups}

\begin{tabular}{|c|c|c|}
\hline Variables & $\begin{array}{c}\text { CG } \\
(\mathrm{n}=38)\end{array}$ & $\begin{array}{c}\text { EG } \\
(n=60)\end{array}$ \\
\hline & & 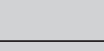 \\
\hline \multicolumn{3}{|l|}{ Sex } \\
\hline Males & 60.5 & 50.0 \\
\hline Females & 39.5 & 50.0 \\
\hline Total & 100.0 & 100.0 \\
\hline \multicolumn{3}{|c|}{$\begin{array}{l}X_{o}^{2}(1)=1.038<X_{t}^{2}(1) 0.05=3.841 \\
\text { SES }\end{array}$} \\
\hline High & 5,3 & 8,3 \\
\hline Medium & 73,6 & 68,4 \\
\hline Low & 21,1 & 23,3 \\
\hline Total & 100.0 & 100.0 \\
\hline
\end{tabular}

$\mathrm{X}_{\mathrm{o}}^{2}(1)=0.070<\mathrm{X}_{\mathrm{t}}^{2}(1) 0.05=3.841 . \mathrm{X} 2 \mathrm{o}$ was calculates joined high + medium categories .

Religion

Adventist

Catholic

Evangelic

Others

Total
11.4

100.0
100.0

$\mathrm{X}^{2}{ }_{\mathrm{o}}(3)=0.006<\mathrm{X}_{\mathrm{t}}^{2}$ (3) $0.05=7.815$.

Age (y)

$$
\begin{array}{lrr}
4.8 \pm 0.7 & & 5.2 \pm 0.9 \\
\text { Student's t } \quad \text { test }=2.230 ; & \mathrm{p}<0.0284
\end{array}
$$




\section{FIGURE 1}

Flow diagram of mother-preschooler dyads and participation rates during the short-term school vegetable gardens education program (VEGAPRO) through each stage of the randomized trial

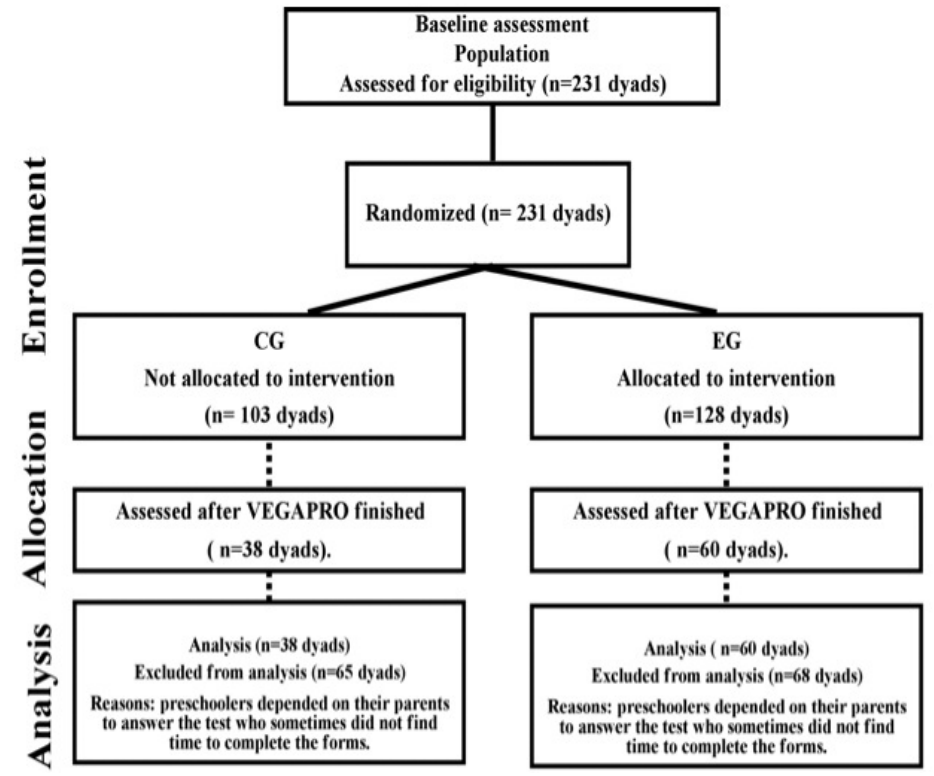

\section{FIGURE 2}

Preschoolers from the experimental group working in the vegetable gardens, preparing the soil, sowing, irrigating, harvesting and consuming the vegetables
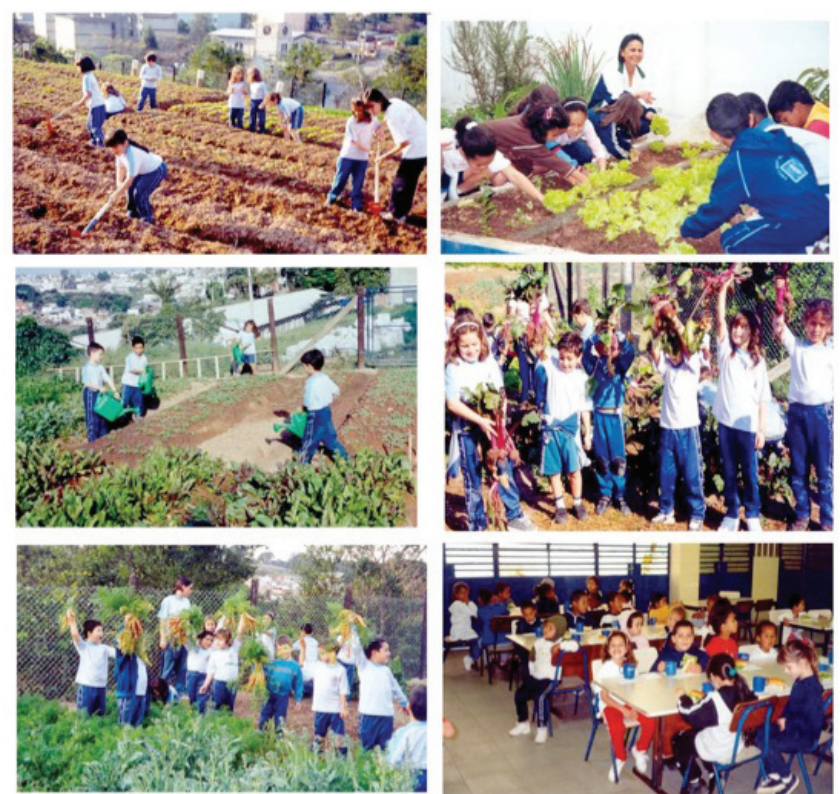
TABLE 2

Methodological design stages.

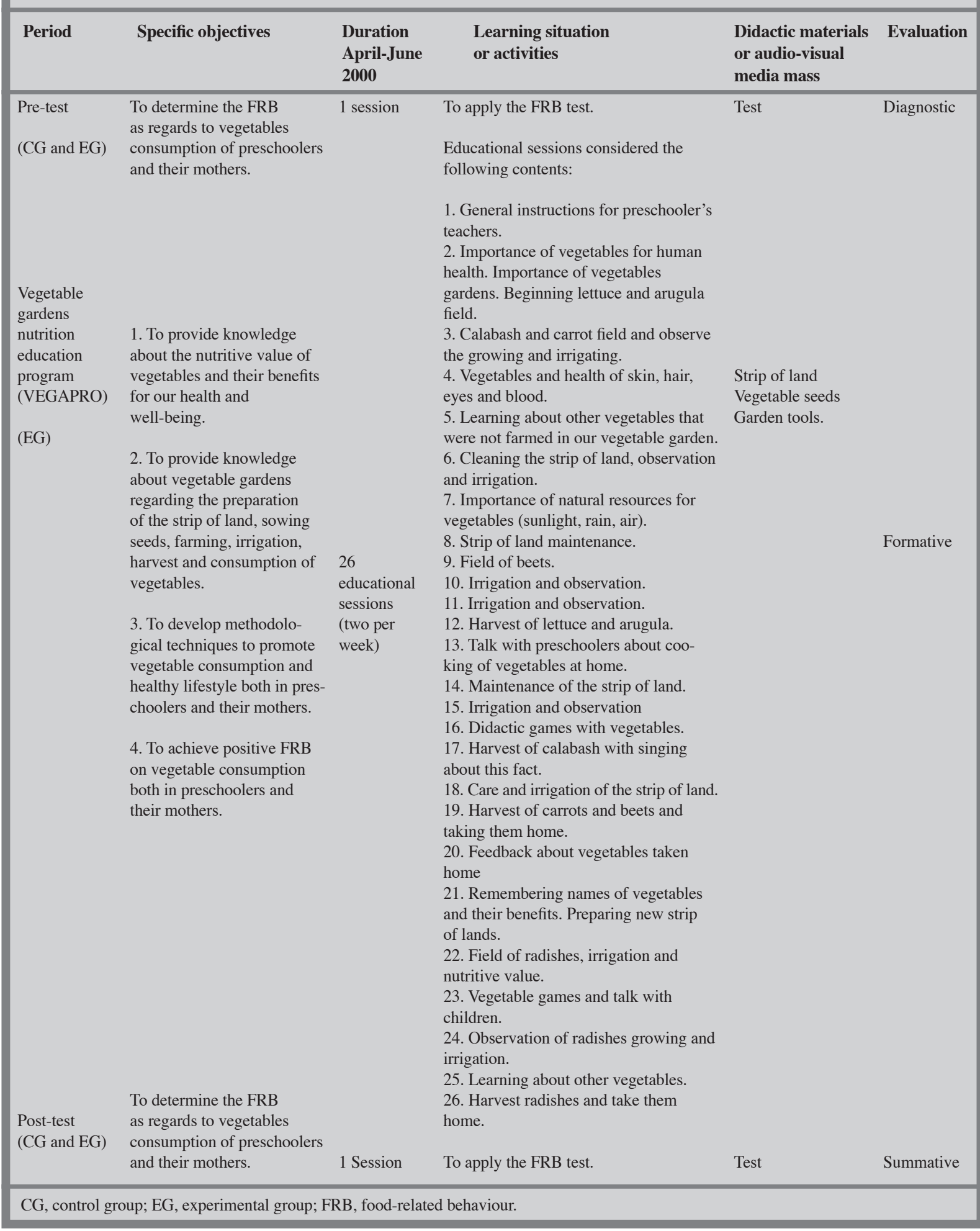


talks were given with each preschooler exposing their opinion to the investigators and to their teacher, with regard to their experiences with the vegetable garden, reinforcing their knowledge about the nutritive value of each vegetable. Games and songs related to each vegetable were part of these activities. Both investigators and preschoolers' teachers registered their opinions and observations in field notes.

The educational strategies to achieve changes on FRB were considered according to the PRECEDE Model, whose determinants are the predisposition of school directors, parents and pupils to help vegetable garden program; parents and pupils manifested the intention of changing negative food-related attitudes throughout their participation in the program (30). The concept of lifestyle was collective since the program was both a group and the individual experience characterized by personal incentive, mutual help, self-care reinforcement and creation of spaces for a healthy life.

\section{Evaluation period (Post-test)}

The post-test period began immediately after VEGAPRO was completed. Like in the pre-test period, food attitudes related to vegetable consumption were assessed applying the same test to both CG and EG (table 2).

\section{Statistical Analysis}

Data were analyzed by means of non-parametric methods such as Mc Nemar's test for independent and paired samples. Student's paired t test was used for comparison of means (31). Data were processed with the Statistical Analysis System (SAS) software (32).

\section{RESULTS}

Table 3 shows the number of daily meals in which preschoolers and their mothers consumed vegetables, analysed by group and study period. Mothers from the EG manifested a significant increase in the number of daily meals in which they consumed vegetables. The percentage of mothers that consumed vegetables on more than one meal per day significantly increased from 61.7 to $75 \%$ in the pre-test and the post-test periods, respectively $(\mathrm{p}<0.01)$. In preschoolers from the EG, despite the fact that these rates increased from 55.2 to $63.8 \%$, respectively, differences were not significant.

The frequency of vegetable consumption by the preschoolers and their mothers is indicated in table 4, by group and study period. No significant differences were found in the dyads from CG and EG. However, among preschoolers from the EG, the percentage that consumed vegetables daily increased from 48.3 to $53.4 \%$, comparing the pre-test and the post-test periods,

\section{TABLE 3}

\section{Number of daily meals in which preschoolers and their mothers consumed vegetables by group and study period.}

\begin{tabular}{|c|c|c|c|c|c|c|c|c|}
\hline \multirow{3}{*}{$\begin{array}{l}\text { Number of } \\
\text { daily meals }\end{array}$} & \multicolumn{4}{|c|}{ CG } & \multicolumn{4}{|c|}{ EG } \\
\hline & \multicolumn{2}{|c|}{ Pre-test } & \multicolumn{2}{|c|}{ Post-test } & \multicolumn{2}{|c|}{ Pre-test } & \multicolumn{2}{|c|}{ Post-test } \\
\hline & n & $\%$ & $\mathbf{n}$ & $\%$ & $\mathbf{n}$ & $\%$ & n & $\%$ \\
\hline \multicolumn{9}{|l|}{ Preschooler } \\
\hline$£ 1$ meal & 15 & 40.5 & 14 & 37.8 & 26 & 44.8 & 21 & 36.2 \\
\hline$>1$ meal & 22 & 59.5 & 23 & 62.2 & 32 & 55.2 & 37 & 63.8 \\
\hline Total & 37 & 100.0 & 37 & 100.0 & 58 & 100.0 & 58 & 100.0 \\
\hline McNemar'sTest & \multicolumn{4}{|c|}{$\mathrm{p}<1.000 \mathrm{NS}$} & \multicolumn{4}{|c|}{$\mathrm{p}<0.1306 \mathrm{NS}$} \\
\hline \multicolumn{9}{|l|}{ Mother } \\
\hline$£ 1$ meal & 15 & 40.5 & 12 & 32.4 & 23 & 38.3 & 15 & 25.0 \\
\hline$>1$ meal & 22 & 59.5 & 25 & 67.6 & 37 & 61.7 & 45 & 75.0 \\
\hline Total & 37 & 100.0 & 37 & 100.0 & 60 & 100.0 & 60 & 100.0 \\
\hline McNemar'sTest & \multicolumn{4}{|c|}{$\mathrm{p}<0.547 \mathrm{NS}$} & \multicolumn{4}{|c|}{$\mathrm{p}<0.01$} \\
\hline
\end{tabular}


respectively. For the mothers, these rates were $61.0 \%$ and $66.1 \%$, respectively.

Figure 3 summarizes the number of vegetables that preschoolers consumed by group and study period. Preschoolers from the CG did not present significant differences in the number of vegetables that they consumed comparing the pre-test $(3.0 \pm 2.2$ vegetables $)$ and post-test $(3.5 \pm 2.3$ vegetables) periods (Student's paired t test $=1.439 ; 38 \mathrm{df}$; NS). However, there was a significant increase in the number of vegetables that preschoolers from the EG consumed comparing the pre-test $(3.2 \pm 5.4$ vegetables $)$ and the post-test $(6.2 \pm$ 9.4 vegetables) periods (Student's paired t test $=2.176$; 59 df; $p<p<0.02$ ).

\section{DISCUSSION}

The findings of the present study confirm the positive impact of VEGAPRO in FRB as regards to vegetables consumption by preschoolers and their mothers, even though this was a short-term study. However, as we stated previously, short-term environmental interventions have low costs, increase availability and therefore increase fruit and vegetable intake in school gardening programs (26).

Taking into account these considerations, VEGAPRO had a significant impact on the number of daily meals in which preschoolers' mothers from the EG consumed vegetables, since expressed as percentage of mothers who consumed vegetables in more than one meal per day this increased by 13.3 points between the pre-test and the post-test periods. This indicates that a reciprocal transference of knowledge from preschoolers to their mothers took place, considering that the mothers did not participate in the program; in fact, preschoolers instructed their mothers as to the benefits of vegetable consumption. This was observed despite the fact that 42.9\% of mother from the CG were Seventh-day Adventists who had a better lifestyle than general population (33). So, they also benefited, since the percentage of children who increased the number of daily meals in which they consumed vegetables increases by 8.6 points. Probably, the mothers also increased the number of meals in which they consumed vegetables seeing the enthusiasm of their children when they worked in their vegetable gardens. This change in the mothers' FRB affected their children's vegetable consumption within a short-time. Nevertheless, differences were not significant. The change observed in the mothers is important since school-age children, regardless of age, identify their mother as the most important source of nutrition information, followed by their teachers and the mass media, mainly television $(34,35)$.

The frequency of vegetable consumption also increased both in the preschoolers and their mothers from the EG, although the differences were not significant. The percentage of preschoolers who consumed vegeta-

\section{TABLE 4}

Frequency of consumption of vegetables of preschoolers and their mothers by group and study period

Frequency of consumption of vegetables

\section{CG}

Pre-test

Preschooler

Daily

Non-daily

Total

McNemar's Test
54.0

46.0

37

100.0

$1.000 \mathrm{NS}$

\section{EG}

Pre-test

n $\%$

28

30

58

100.0

37

69.423

63.9

36

61.0

$39 \quad 66.1$

Non-daily

11

30.613

36.1

23

$100.036 \quad 100.0 \quad 59$

McNemar's Test
9.0

100.0

\section{3}

51.7

100.0

$0.5465 \mathrm{NS}$
Post-test

n $\%$

$31 \quad 53.4$

$27 \quad 46.6$

$58 \quad 100.0$

CG, control group; EG, experimental group; NS, not significantly different. 
bles daily increased 5.1 percentage points comparing the pre-test and post-test periods; the percentage of mothers also increased similarly. This could be also indicative of the transference of knowledge from child to mother and vice versa.

Another important finding of the study was the significant impact of VEGAPRO in the number of vegetables that preschoolers from the EG liked to consume compared with their peers from the CG. Some statements by the preschoolers and registered by the teachers were "I had never eaten calabash, I ate it and I liked it"; "Beet is delicious with beans"; "Oh, teacher, carrots are not as bad as I had thought. "It tastes nice with bread". Another teacher comments: "Some mothers emphasized that VEGAPRO contributed to stimulate children to eat all that they planted and cared for with their own hands". Other teachers said: "This program provided children with the opportunity for learning about God and His Creation power"; "I think that the duration of the program can be increased, but this intervention has been the beginning of a work that already has given results"; "With the knowledge acquired at school, some preschoolers created a vegetable garden at home". The principal of one of the educational establishments said:
"Children experienced some that the minority of children from São Paulo city never experienced, the aroma of land and the flavour of vegetables that they will never forget. From their hands I received as a gift the vegetables cooked by themselves. For me, this was an unforgettable experience and for parents it was also a surprise since they didn't hope that their children would understand so much of vegetables gardens".

People who directly or indirectly participated in VEGAPRO felt the satisfaction of the results related to the positive changes in FRB of the dyads that joined the program. Preschoolers not only harvested all that they planted, but they also consumed the vegetables. Children were informed, in a basic language according to their chronological and psychological age, of the nutritional value of vegetables and of the health reasons for their consumption. VEGAPRO also served as a vehicle for teaching as the program was to teach different subjects of preschool level. This is in agreement with findings by other authors who concluded that a school-based garden enabled the teaching of basic nutrition as part of the core school curriculum (24). Other investigators have emphasized that teachers perceived the garden to be effective in enhancing academic performance,

\section{FIGURE 3}

Number of vegetables (mean \pm DE) that preschooler like to consume by group and study period.

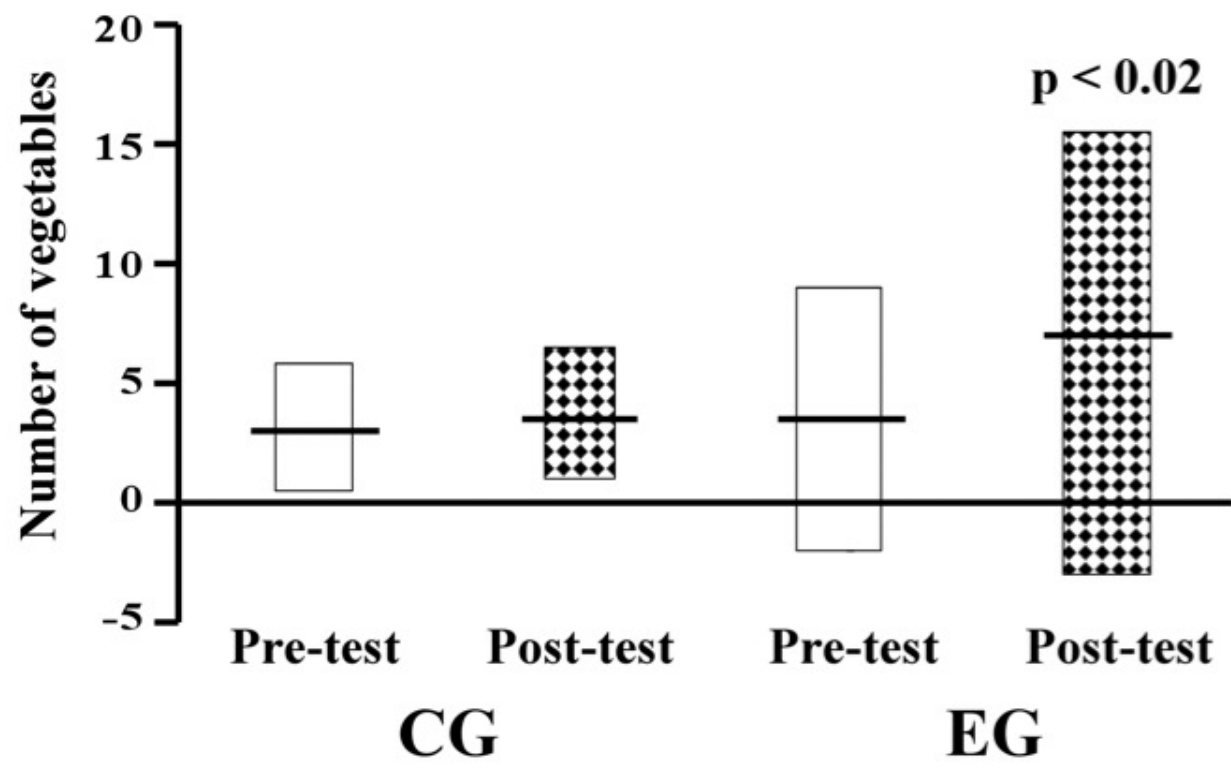

Note. CG: control group; EG: experimental group. 
physical activity, language abilities and healthful eating habits (36). School gardens are used by schools in the United States to enhance teaching. There is a need for curriculum materials and teacher training on gardening and nutrition. The link between gardens and the school meal program is an area that requires the attention of the school authorities. The school lunch would be a logical setting for taste-testing of fresh vegetables (37). In our study, this concept was an innovative, practical nutritional education tool to build the capacity of preschoolers, their families and the school staff in the improvement of FRB as regards to vegetable consumption.

The program had a positive impact both for children and their families. Principals and teachers concluded that the vegetable gardens program not only improved food habits but it favoured self-esteem, cooperation, motivation, favoured the child's motor and cognitive development, improved sociability between children and teachers and favoured training on group work. Nevertheless, recent reviews summarize the literature available regarding the impact of school gardening curricula on student or school functioning; this provides a conceptual framework to guide future inquiry, discuss the implications of conceptualization in relation to practice, and suggests that further research needed to improve practices, since of all the efforts developed to improve the nutritional situation of the community, promotion of positive food behaviours are among the most difficult tasks (23). Other authors also describe that although further research is needed, the nutrition intervention programs seem to indicate the efficacy of using garden-based nutrition education to increase adolescents' consumption of fruits and vegetables (38). The findings from other authors emphasize that youth (age 8-15 years) in the garden program consumed more fruits and vegetables at post-survey compared to pre-survey and conclude that garden programs may be a viable way to assist youth in making healthy lifestyle changes (39).

The finding of the present study confirm the hypothesis that (i) preschoolers enrolling in VEGAPRO increase the number of daily meals and the frequency with which they consume vegetables, as well as the number of vegetables that they like to consume and (ii) mothers experience positive changes in their FRB under their children's influence. Considering that VEGAPRO was a study and a simple short-term intervention, it represented an interesting activity focused mainly on preschoolers; it was also useful for their mothers. In summary, this was a successful experience that pinpoints the need for further research, especially long-term studies to improve FRB starting at an early age to prevent chronic nontransmissible diseases in the adult life.

\section{RESUMEN}

El propósito de este estudio fue evaluar el impacto de un Programa de Huertas Escolares (PEHE) de corta duración, dirigido a preescolares y sus madres, sobre el comportamiento alimentario, en relación al consumo de verduras (CAV). La población total, 231 díadas madrepreescolar fueron aleatoriamente distribuidas en: grupo control (GC, $n=103$ ) sin participar en el PEHE, y grupo experimental (GE, $n=128)$, con participación de los preescolares en el PEHE; sin embargo, en el GC y GE, 38 y 60 díadas, respectivamente, finalizaron el programa. Los preescolares del GE incrementaron el número de comidas diarias y la frecuencia semanal en que ellos consumían verduras, como igualmente el número de verduras que consumían $(\mathrm{P}<0.02)$. Las madres del GE aumentaron significativamente el número de comidas diarias en que consumían verduras $(\mathrm{P}<0.01)$. Los hallazgos ponen de manifiesto la importancia de implementar un PEHE desde temprana edad para promover estilos de vida saludables.

Palabras clave: educación para la salud, promoción de la salud, verduras, comportamiento alimentario, Brasil.

Corresponding author:

Professor

Daniza M. Ivanovic

Institute of Nutrition and Food Technology (INTA) University of Chile,

Phone (56) 2-678-1459

FAX (56) 2- 221-4030.

E-mail: divanovic@inta.cl

Acknowledgements: Authors grateful acknowledge all the help provided by the educational establishments from São Paulo in which this study was carried out; we are also thankful to Dr. Oscar Brunser, MD, for all the helpful comments and suggestions and to Ms. Nora S. Diaz, from the University of Chile, Institute of Nutrition and Food technology (INTA), for statistical assistance. This study was supported by Grant from the Family Health Program, UNASP, São Paulo. Brazil. The data for the present manuscript are part from a thesis submitted by the first author Rachel Gonçalvez Miguel, in partial fulfilment of the requirements for the Master of Public Health Program, School of Public Health, Loma Linda University, California, United States.

\section{REFERENCES}

1. Perez-Rodrigo C, Aranceta Bartrina J, Serra Majem L, Moreno B, Delgado Rubio A. Epidemiology of obesity in Spain. Dietary guidelines and strategies for prevention. Int J Vitam Nutr Res 2006;76:163- 
2. Dastgiri S, Mahdavi R, TuTunchi H, Faramarzi E. Prevalence of obesity, food choices and socio-economic status: a cross-sectional study in the northwest of Iran. Public Health Nutr 2006;9:996-1000.

3. Smith-Warner SA, Spiegelman D, Yaun SS, Albanes $\mathrm{D}$, Beeson WL, van den Brandt PA, et al. Fruits, vegetables and lung cancer: a pooled analysis of cohort studies. Int J Cancer 2003;107:1001-11.

4. Persky VW, Chatterton RT, Van Horn LV, Grant MD, Langenberg P, Marvin J. Hormone levels in vegetarian and non vegetarian teenage girls: potential implications for breast cancer risk. Cancer Res 1992;52:578-83.

5. Singh PN, Fraser GE. Dietary risk factors for colon cancer in a low-risk population. Am J Epidemiol 1998;148:761-74.

6. Fraser GE, Shavlik DJ. Risk factors for all-cause and coronary heart disease mortality in the oldestold. The Adventist Health Study. Arch Intern Med 1997;157:2249-58.

7. Hyson D. The health benefits of fruit and vegetables. A Scientific Overview for Health Professionals. Washington: Produce for Better Health Foundation. 2002.

8. Produce for Better Health Foundation. 5 a day for Better Health Program. Monograph. Washington: National Institute of Health (NIH)-National Cancer Institute (NCI). 1999.

9. Produce for Better Health Foundation. 5 a day for Better Health. Programme Guide book. Washington: Produce for Better Health Foundation (PBF)- National Cancer Institute (NCI). 1999.

10. World Health Organization. Diet, Nutrition and the prevention of chronic diseases. Report of a join WHO/FAO expert consultation. WHO Technical Report series 916. Geneva: WHO. 2003.

11. World Health Organization. Fruit And Vegetables Promotion Initiative. Report of the meeting. Geneva: WHO. 2003.

12. Reynolds KD, Franklin FA, Binkley D, Raczynski JM, Harrington KF, Kirk KA, et al. Increasing the fruit and vegetable consumption of fourthgraders: results from the high 5 project. Prev Med 2000;30:309-19.

13. Reynolds KD, Raczynski JM, Binkley D, Franklin FA, Duvall RC, Devane-Hart K, et al. Design of "High 5": a school-based study to promote fruit and vegetable consumption for reduction of cancer risk. J Cancer Educ 1998;13:169-77.

14. Maruya N, Kawabata T, Nakamura M, Ohshima A, Minagawa K, Nishioka N, et al. Knowledges of foodstuffs in relation to adult diseases in Japanese students--results from Japan Know Your Body Study. Nippon Koshu Eisei Zasshi 1994; 41:558-68.

15. Jabre B. Innovative approaches in nutrition education in the Pacific region. Int $\mathbf{J}$ Health Educ 1981;24:95-101.

16. Lee RL, Loke AJ. Health-promoting behaviors and psychosocial well-being of university students in Hong Kong Public Health Nurs 2005;22:209-20.

17. Kim HS, Lee CY, Lee TW, Ham OK. Health problems and health behaviors of preschoolers. Taehan Kanho Hakhoe Chi. 2004;34:182-90.

18. OMS. Prevención en la niñez y en la juventud de las enfermedades cardiovasculares del adulto. Serie de Informes Técnicos 792. Ginebra: OMS; 1990.

19. Chauliac M, Barros T, Masse-Raimbault A, Yepez R. Jardins scolaires et éducation alimentaire en milieu andin. FNA/ANA 16. Roma: FAO;1996.

20. Foster V. Retorne a lo natural! Viva más y mejor. Buenos Aires: Asociación Casa Editora Sudamericana; 1998. p. 376-7.

21. Morris JL, Zidenberg-Cherr S. Garden-enhanced nutrition curriculum improves fourth-grade school children's knowledge of nutrition and preferences for some vegetables. J Am Diet Assoc 2002;102(1):91-3

22. Morris JL, Koumjian KL, Briggs M, ZidenbergCherr S. Nutrition to grow on: a garden-enhanced nutrition education curriculum for upper-elementary schoolchildren. J Nutr Educ Behav 2002;34:175-6.

23. Ozer EJ. The Effects of School Gardens on Students and Schools: Conceptualization and Considerations for Maximizing Healthy Development. Health Educ Behav 2007 ;34:846-63.

24. Viola A. Evaluation of the Outreach School Garden Project: building the capacity of two Indigenous remote school communities to integrate nutrition into the core school curriculum. Health Promot J Austr 2006;17:233-9.

25. Salay E, de Carvalho JF. Evaluation of the schoollunch program in Campinas, Brazil. Arch Latinoam Nutr 1995:45:167-171

26. French SA, Wechsler H. School-based research and initiatives: fruit and vegetable environment, policy, and pricing workshop. Prev Med. 2004;39(Suppl 2):S101-7.

27. Gifft $\mathrm{H}$, Washbon M, Harrison. Nutrition, behavior and change. Englewood Cliffs, NJ: Prentice Hall. 1972; p. 350-1.

28. Alvarez, M de la L, Muzzo S, Ivanovic D. Escala para la medición del nivel socioeconómico en el área de la salud. Rev Med Chile 1995;113:243-9. 
29. The World Medical Association. Human experimentation. Code of Ethics of the World Medical Association (Declaration of Helsinki). Br Med J 1964;2:177.

30. Green LW, Kreuter M. Health promotion planning: An educational and ecological approach. Third edition. Portland OR: McGraw-Hill; 1999.

31. Guilford JP, Fruchter B. Estadística Aplicada a la Psicología y a la Educación. México: McGraw Hill; 1984.

32. SAS. SAS Introductory Guide. Statistics. North Caroline: SAS Institute Inc., Cary; 1983.

33. Kamieneski R, Brown CM, Mitchell C, Perrin KM, Dindial K. Health benefits achieved through the Seventh-Day Adventist Wellness Challenge program. Altern Ther Health Med 2000;6:65-9.

34. Ivanovic R, Truffello I, Buitrón C, Ivanovic D. Educational factors influencing the nutritional learning of elementary first grade Chilean students. Nutr Rep Int 1989;39:1161-66.
35. Ivanovic R, Olivares M, Ivanovic D. Sources of nutrition information of Chilean schoolers, Metropolitan Region, Chile, Survey 1986-1987. Arch Latinoam Nutr 1991;41:527-38

36. Graham H, Zidenberg-Cherr S. California teachers perceive school gardens as an effective nutritional tool to promote healthful eating habits. J Am Diet Assoc 2005;105:1797-800.

37. Graham H, Beall DL, Lussier M, McLaughlin P, Zidenberg-Cherr S. Use of school gardens in academic instruction. J Nutr Educ Behav, 2005;37:14751.

38. McAleese JD, Rankin LL. Garden-based nutrition education affects fruit and vegetable consumption in sixth-grade adolescents. J Am Diet Assoc 2007; 107:662-5.

39. Lautenschlager L, Smith C. Understanding gardening and dietary habits among youth garden program participants using the Theory of Planned Behavior. Appetite $2007 ; 49: 122-30$. 